\title{
Major Salivary Gland Cancer pT4a TNM Finding v7
}

National Cancer Institute

\section{Source}

National Cancer Institute. Major Salivary Gland Cancer pT 4a TNM Finding v7. NCI

Thesaurus. Code C89121.

Major salivary gland cancer with moderately advanced disease. Tumor invades skin, mandible, ear canal, and/or facial nerve. (from AJCC 7th Ed.) 